\title{
Stock Returns and Fundamentals in the Australian Market
}

\author{
Noor Muhammad (Corresponding author) \\ The University of Waikato, Hamilton, New Zealand \\ E-mail: uighor@yahoo.com
}

Frank Scrimgeour

The University of Waikato, Hamilton

New Zealand

Received: April 16, 2014 Accepted: May 15, $2014 \quad$ Published: June 1, 2014

doi:10.5296/ajfa.v6i1.5486 URL: http://dx.doi.org/10.5296/ajfa.v6i1.5486

\begin{abstract}
This study compares 10 widely used financial performance measures of stock return in the Australian stock market. The five financial measures are calculated on information provided in publicly available financial reports (accounting based financial measures) and the other five are calculated using market information as one of the key variable (market based financial performance). The sample includes companies from all major industries from 2001 to 2010. The panel data analysis shows that market based financial performance measures can better explain stock price variance compare to accounting based measures of financial performance. It has significance for researchers and practitioners seeking to select measures that can empirically explain the performance of company. It has also importance for shareholders tracking performance of companies in order to make profitable investments.
\end{abstract}

Keywords: Accounting based performance, Market based performance, Stock price, Investment 


\section{Introduction}

Each measure of corporate performance is very important for a range of stakeholders. It is not only used by internal stakeholders for decision making but also by external stakeholders including creditors and competitors. Performance evaluation is normally looked at in the context of published financial statements but in reality performance measures have broader scope and implications. Corporate performance is perceived in different ways such as return, production efficiency and financial growth. A number of studies over a long period have emphasized the usefulness of financial fundamentals (Chen \& Shimerda, 1981). Financial ratios allow shareholders to compare different information in a meaningful way in order to make investment decisions (Singh \& Schmidgall, 2002). Ratio analysis provides information that summarizes the strengths and weaknesses of different corporations from return, liquidity and growth perspectives.

When evaluating firm performance, the most common fundamentals/ratios are related to profitability and returns. These financial ratios are based on publicly published financial statements and known as Accounting-based Financial Performance (AFP). These performance measures offer significant financial information to both shareholders and researchers to assess different corporations and compare their standing within an industry over the years (Gallizo \& Salvador, 2003).

Many traditional financial performance measures are reported in the literature. However, these measures are grouped on the basis of the nature of their information. Financial markets have become more competitive in recent years which make efficient uses of resources a vital and challenging issue. Diversification in form of products and markets often increases corporation income and enhance their value (He, 2012; Olibe, Ehie, \& Strawser, 2012; Pandya \& Rao, 1998). A successful corporation requires excellent performance measurement tools that are suitable and aligned with a value maximization objective.

Conventional accounting based financial performance measures have been criticized for providing ineffective guidance when making strategic decisions. These shortcomings are addressed by market based financial measures. Market price based financial measures have attracted increasing attention as alternatives to measure value for firms (Sandoval, 2001).

International strategy research and behavioural finance theories show that firm financial performance is substantially influenced by contextual phenomenon (Tong, Alessandri, Reuer, \& Chintakananda, 2008) and it varies in different market and sectors. For example, stating the purpose of earning per share, accounting standards ${ }^{1}$ argue that it provides information on comparisons between different entities in the same reporting period and between different reporting periods for the same entity but following this fundamental principle empirical studies found confounding results.

Nikolai and Bazley (2010) consider earning per share (EPS) as a helpful measure to evaluate return over investment and risk taken by a firm. Whereas, Cudia and Manaligod (2011) refute this claim and consider that EPS fails to effectively compare financial performance between

\footnotetext{
${ }^{1}$ International Financial Reporting standards (IFRS) 33
} 
companies. Jordan, Clark, and Smith (2007) also pointed out some pitfalls of this measure of performance. They suggest that EPS may be used for large companies but it should be avoided for small listed companies' analysis as it is poor measure for firms of different size and thus is not useful for intercompany comparison.

The motivation of this study is to empirically identify appropriate financial performance evaluation tools from a range of available tools for ASX 200 companies. It also compares whether accounting based financial measure or market based financial measures better explain variance in stock prices. This is an important area to be researched as ratios are often used for financial performance evaluation intuitively without considering their theoretical and statistical properties.

In the next section, we cover historical background and development of ratio analysis. Section 3 and section 4 discusses accounting based ratios and market based ratios respectively. Section 5 covers methodology used for this research followed by results and discussion in section 6 . The last section concludes the study.

\section{Background}

The word ratio is originally taken from the Latin verb reri, to think; past participle, ratus (Smith, 1925, p. 478). Thus, ratio in Latin means calculation, relation or reason. In other words ratio is the relationship of one amount to another. Theoretically, when one term (numerator) is divided by another term (denominator), the resultant number is called the ratio of the first term to the second term. It is difficult to establish the first use of ratio but some Greek writers like Nichomachus used it in arithmetic, Eudoxus used it in geometry and Theon used it in music (Smith, 1925, pp. 477-478). It is believed that the Babylonians had some concept of ratio in 2200 B.C. (Bell, 1945, p. 41). The science of ratio analysis can also be found in the elements of Euclid's approximately 300 B.C.(Anjum, 2010; Horrigan, 1968). However, modern ratios and their use started in the late nineteenth century in the United States when corporations were growing and had great impact on different stakeholders. Creditors were concerned for the stability of firms whereas shareholders were interested in profitability. During the late nineteenth century, the flow and volume of financial information increased significantly. In this period credit analysis dominated as creditors were very keen to access financial statements to conduct credit analysis (Horrigan, 1968). The most common practice of this time was the comparison of current assets with current liabilities (current ratio) (Anjum, 2010; Horrigan, 1968).

In the first two decades of the twentieth century several financial ratios emerged. Some were used with an absolute criterion ${ }^{2}$ while others were to address the need for inter-company comparisons (Horrigan, 1968). Wall (1919) probably conducted the first formal study by analysing 981 firms using 7 different financial ratios. He categorized these firms in different geographic locations and different sectors. He found great variation in performances between different sectors and geographic locations. Despite Wall's fuzzy method, variability of

\footnotetext{
${ }^{2}$ For lending purposes a current ratio of 2:1 was used as a judgement criterion (Horrigan, 1968, p. 285)
} 
involved factors and trouble in collecting comparable financial data, it still has historical importance as a pioneer in the use of ratios (Anjum, 2010; Horrigan, 1968).

About the same time, the du Pont Company came up with the du Pont pyramid. The top of this matrix is return on investment and the base consists of profit margin and capital turnover ratios. This system encouraged the development of a logical order of ratio and financial performance (Horrigan, 1968).

After the Wall (1919) study, two schools of thoughts emerged in next decade. One viewed ratios as fundamental measures of the business enterprise (Bliss, 1923) and on the contrary the other school of thought viewed it as artificial measure of business enterprise (Gilman, 1925). Bliss (1923) presented ratios in a coherent fashion and considered them as "indicators of the status of fundamental relationship within a business" (p.34). On the other hand, Gilman (1925) criticised ratios for using inconsistent and incomparable accounting data in computation. In ratio calculations both numerators and denominators vary over time, therefore, ratios are artificial measures of financial performance that distract analyst attention from a broader view of the company.

After passing of legislation ${ }^{3}$ in the United States regarding the content, quality and consistency of financial information, the science of analysing financial performance became more sophisticated and effective (Horrigan, 1968). Small and medium business enterprises also started to publish work on ratio analysis. Analysts were keen to look at the predictive power of ratio analysis with new dimensions. For example, Sorter, Becker, Archibald, and Beaver (1964) investigated the relationship of a financial ratio to a psychological model of the corporate personality and found that conservative firms maintain higher cash and solvency.

After the invention of modern statistical analysis and electronic data processing tools, studies regarding empirical effectiveness of ratio analysis also increased (Salmi \& Martikainen, 1994). One of the important topics that is discussed in financial performance evaluation research is the distributional properties of ratios. A number of studies support the view that the majority of financial ratios are not normally distributed (Deakin, 1976; Ezzamel \& Mar-Molinero, 1990; Ezzamel, Mar-Molinero, \& Beech, 1987).

Deakin (1976), in his study rejected normal distribution assumption for the majority of studied ratios. He further claimed that normality can only be achieved by transformation of data. However, he was not sure that what kind of data transformation can produce the best results. Ezzamel and Mar-Molinero (1990) conducted a study to examine the cross-sectional and inter-temporal distribution properties of financial ratios in United Kingdom listed companies. They conducted several tests and concluded that the assumption of normality is rejected. Transformation of raw data did not improve the normality assumption for their sample. However, if transformation is necessary then the cubic root seems to be a better alternative to the natural logarithm and square root.

\footnotetext{
${ }^{3}$ The Security Act of 1933 and Securities and Exchange Act of 1934
} 
Lev and Sunder (1979) studied methodological issues pertaining to ratio analysis. Particular attention was given to the conditions under which a ratio can achieve its intended objective. They concluded that both practitioners and researchers use ratios because of convenience and tradition rather than careful methodological investigation. The objective of their study was "to encourage the user of financial ratios to examine carefully the adequacy of using ratios in their analysis." (p.209).

Salmi and Martikainen (1994) reviewed financial ratio analysis research. On account of their classification of financial ratios, they categorised them in four sets: pragmatic empiricism ${ }^{4}$, a deductive approach ${ }^{5}$, an inductive approach ${ }^{6}$ and a combination of deductive and inductive approaches and called the confirmatory approach ${ }^{7}$. Their review of the literature revealed that financial ratios can be reduced to only 4-7 indispensable ratios but empirical evidence is divided on this issue. This study relies on the confirmatory approach.

\section{Accounting-based financial performance measures}

In this study, five accounting measures are determined as the sub-criteria of the AFP main-criterion to evaluate companies in ASX 200. These measures are return on assets (ROA), return on equity (ROE), earning per share (EPS), free cash flows (FCF) and pay-out ratio (POR). These sub-criteria are briefly explained in the following.

\subsection{Return on assets (ROA)}

This financial statement measure is comparing corporation profitability in a given year to the corporation's average total assets. The return on assets ratio is expressed in the form of a percentage. This accounting measure of profitability has significant importance because it shows the effective and efficient use of firm total assets to generate earnings. Alternatively, return on assets shows the amount of profit a firm generates for each unit of investment in assets (Palepu et al., 2010). There is slightly variation in formulation of this measure in the literature. We adopt the Palepu et al. (2010) measure of ROA:

$$
R O A=\frac{\text { Earning Before Interest and Tax (EBIT) }}{\text { Average Total Assets }}
$$

Palepu and colleague used earning before the interest and taxes as the numerator as opposed to Moyer, McGuigan, and Kretlow (1992) who used net income. As the purpose of return on an asset does not account for whether assets are financed through equity or debt. The net income measure is adjusted for the interest expense as well as other items such as taxation. To remove the effect of financing choice, EBIT is a better choice (Palepu et al., 2010). Return on asset formulation shows that investors favour a higher ratio because it is a proxy for the performance of a company. ROA also shows the efficiency of management in using firm

\footnotetext{
4 "a subjective classification of financial ratios based on the practical experience or views of the authors" (Salmi \& Martikainen, 1994)

${ }^{5}$ Using earlier work, deliberation, logic, reasons or even visual approximation to form a relationship (Salmi \& Martikainen, 1994)

6 A method that has emphasis on empirical evidences rather than theoretical foundation (Salmi \& Martikainen, 1994).

7 An approach that hypothesize priori relationship and investigate it empirically (Salmi \& Martikainen, 1994).
} 
assets to generate earnings. Similarly, ROA is a helpful measure in comparing a company's performance with its competitors.

\subsection{Return on equity (ROE)}

Return on equity is also referred to as return on common shareholder equity (ROCE). The primary factor that distinguishes ROE and ROA is the company debt financing. In other words financial leverage changes ROA and ROE. In the absence of company liabilities, total assets and shareholders' equity will be the same and hence ROE and ROA would also be the same. Financial leverage gives rise to a ROE greater than ROA due to the comparatively cheaper cost of debt financing. Return on equity is a comprehensive indicator of a firm performance because it measures the percentage of profit earned on common stockholders' investment in the firm. ROE is also useful for comparing the profitability of a firm with rivals in their industry. It is the most significant and widely used financial ratio in manufacturing companies. Theoretically, if a company is motivated to maximize the wealth of its stockholders, it should be trying to maximize ROE. The most common method of ROE calculation is as follows (Livingstone \& Grossman, 2002; Palepu et al., 2010):

$$
R O E=\frac{\text { Income available to common shareholder }}{\text { Average common shareholder's equity }}
$$

Only the stockholder's equity appears in the denominator, for this reason the numerator needs to be adjusted for the payment attributed to preferred shareholders. If the firm has not issued preferred share equity of any other priority capital then no adjustment is required.

In measuring the denominator Palepu et al. (2010) suggest that average common shareholder equity should be used to ensure measurement unit consistency, and to compensate for any rapid growth or major changes in shareholders' equity. Higher ROE show efficient management of the equity base and also the better return to its investors.

In the long run, the value of the firm's equity is determined by the relationship between its ROE and its cost of equity capital. In other words, firms that are expected to generate ROE in excess of the cost of equity capital should have a higher market value compared to book value, and vice versa (Palepu et al., 2010).

A comparison of ROE with the cost of capital is useful not only for contemplating the value of the firm but also in considering the path of future profitability. The generation of a consistently higher profit will attract more competition in the absence of significant entry barriers. That is why ROE tends to decline towards the cost of equity over time because of competitive forces. Thus, the cost of equity capital can be used as a benchmark for the ROE that would be observed in a long run competitive equilibrium.

\subsection{Earnings per share (EPS)}

An absolute measure of income does not show the real performance of companies. Therefore, shareholders are interested in how income is changing relative to other factors such as company size (Cudia \& Manaligod, 2011). Earnings per share is an important measure of a company's financial performance. It evaluates economic strength relative to firm size. 
According to Williams (2000), earning per share is an important ratio to analyse the historical operating performance of a firm and help to form an opinion about its potential. EPS is used as an important variable in determining a share market price. A market reacts and makes adjustments to firm earning expectations (Jordan et al., 2007). This ratio determines the relationship between firm profitability and size. Therefore, the majority of studies used the number of ordinary shares outstanding as a proxy to measure firm size. If the number of ordinary shares in the market has changes in a given period because of share buyback then a weighted average of the quantity of shares is used (Yalcin, Bayrakdaroglu, \& Kahraman, 2012).

$$
E P S=\frac{\text { Net Income Available to Ordinary Shareholders }}{\text { Number of Shares Outstanding }}
$$

EPS is very important to most stakeholders. Shareholders are using this information to evaluate the return on their capital. This ratio ignores the capital make up. For example, a company with less equity may have the same EPS as a company that has more equity in their capital. Despite its weakness, EPS is often considered as the single most important measure of a company's profitability (Yalcin et al., 2012).

\subsection{Free cash flows and dividend pay-out ratio}

One way to increase the value of a firm is by limiting the cash out the flows in form of dividend payments. This is because investors may prefer dividend payments only if acceptable capital investment opportunities do not exist. It is widely accepted that profitable capital opportunities increase firm value and internal financing (retained earnings) is the cheapest mode to finance such profitable projects. Issuing new shares results in floatation cost and therefore is less attractive compared to internal financing. Thus, the dividend should only be paid when free cash flows are more than the new capital budget requirements.

The free cash flow hypothesis favours dividend payments in the absence of new investment opportunities. In other words if a firm cannot generate a return equal to the internal rate of return then it is better to pay retained earnings in the form of dividends. Investors react differently to identical changes in dividend by similar firms. Some investors may consider reduction in dividend as a signal for new profitable opportunities. These investors consider that a firm may be interested to accumulate cashflows by reducing dividend payments and thus increases its value. On the other hand, some investors consider reduction in dividend as a negative signal. Because they think that reduced dividend is not in their best interest as it may increase agency problems. Thus the free cash flows and dividend pay-out ratio may be used as an indication of firm investment opportunities.

$$
F C F=N C F-O C F
$$

Where NCF is net cash flow and OCF is operating cash flow. Operating activities represent the net cash receipts and disbursements resulting from the operations of the company. It is the sum of funds from operations, Funds from/used for other operating activities and extraordinary items. 


\section{Macrothink}

The dividend pay-out ratio is formulated as follows

$$
P O R=\frac{D}{E P S}
$$

Where POR is dividend pay-out ratio, D is dividend per share, and EPS is earning per share.

\section{Market-based financial performance measures}

In this study, five market measures are selected as the sub-criteria of the MFP main-criterion to evaluate ASX 200 listed companies. These measures are determined as price earnings ratio (PE), Tobin's q (TBQ), market to book value ratio (M2B), Market Value Added (MVA) and cash flow return on investment (CFROI). These sub-criteria measures are briefly explained in the following.

\subsection{Price earnings ratio $(P / E)$}

The price earning measure shows the amount an investor is willing to pay per unit of earnings announced in the income statement. Shareholders look at several factors before making investment decisions in favour of a particular company. Despite the range of available tools, the price earnings ratio is the most powerful measure of financial performance (Kumar \& Warne, 2009). It is calculated by dividing the current market price per share of stock by earning per share (Truong, 2009):

$$
\text { Price Earning Ratio }=\frac{\text { Market Price per Share }}{\text { Earning per Share }}
$$

Annual earnings available to common shareholder are reported in the income statement, the number of shares outstanding in reported in the statement of financial position and the market price per share of stock is can be obtained from secondary market such as stock exchange.

\subsection{Tobin's $Q(T B Q)$}

This market based performance ratio was first developed by Tobin ${ }^{8}$ in 1969. It measures the market value of a firm relative to the replacement cost of its assets. In other words, it is the intangible assets market worth in the form of tangible assets (Chung \& Pruitt, 1994). A TBQ value above one shows that a firm's assets could be purchased more cheaply than the firm itself and the market is overvaluing the company, while TBQ ratios less than one indicate that market is undervalued in the company.

Tobin's Q plays an important role in explaining diverse corporate financial phenomenon such as investment strategies ${ }^{9}$ contribution to firm value (Jose et al., 1986), common equity structure and its relationship with corporate value (McConnell \& Servaes, 1990), acquiring firm investment opportunities that lead to the different method of payments in corporate acquisitions (Martin, 1996) and time series patterns of excellence (Jose, Lancaster, \& Stevens, 2011).

\footnotetext{
${ }^{8}$ The Tobin Q metric is named after the economist and Nobel winner James Tobin.

${ }^{9}$ Investment strategies are referred to research \& development, promotion and diversification in multiproduct companies (Jose, Nichols, \& Stevens, 1986)
} 
Despite Tobin's Q leading role in several corporate financial areas, managers do not commonly use this powerful tool in practical financial decision analysis. Part of this reluctance is probably because of the abstract and multi-dimensional nature of $\mathrm{Q}$ and top management unfamiliarity with Q (Chung \& Pruitt, 1994).

Unlike other financial performance variables Q data is not directly available on popular databases. Therefore, it can be calculated by applying Lindenberg and Ross (1981) algorithm. This procedure is so difficult and lengthy that even a dedicated analyst would rarely try to attempt it (Chung \& Pruitt, 1994). Hence a simple approximation of Q developed by Perfect and Wiles (1994) can be used.

$$
\text { Appoximate } Q=\frac{M V A+P S+D e b t}{\text { Total Assets }}
$$

Where MVA is the product of a firm's share price and the number of common stock outstanding, PS is product of firm's preferred stock price and number of preferred stock outstanding.

The simplified procedure involved in the calculation of $\mathrm{Q}$ shows a compromise between analytical precision and calculation efforts. The true measure of any such simplification technique is its degree of accuracy when compared with values obtained from following the theoretically more correct model (Chung \& Pruitt, 1994). However, Perfect and Wiles (1994) found 0.9856 observed correlation between simplified Q with Lindenberg and Ross (1981) Q through empirical investigation of 62 firms. Thus simple estimation of Q continues to be a useful measure of financial performance (Chung \& Pruitt, 1994).

\subsection{Market to book ratio (M2B)}

Finance and economic practitioners are continuously searching for variables that can explain the variance and predict stock returns. The market to book ratio became a strong candidate after Fama and French (1992) results showed that the market to book ratio of individual stocks has the ability to explain cross sectional variation in stock returns. The formulation of this formula is as follows:

$$
\text { Market to Book value }=\frac{\text { Market of Equity }}{\text { Book Value of Equity }}
$$

This ratio is used by practitioners and academia to analyse whether a stock price is undervalued or overvalued. If a stock is undervalued, the price is expected to rise. If it is overvalued, the price is expected to fall. In other words, this ratio looks at the worth that market places on the book value of a firm.

\subsection{Market Value Added (MVA)}

The way in which shareholder wealth is increased is by maximizing the difference between firm total market value and the amount of capital that investors have supplied to it. This difference is called MVA (Gapenski, 1996). Market value added is the aggregate measure of wealth created by the management in addition to the shareholder investment (Kramer \& 
Peters, 2001). Although shareholder investment is recorded historically and is subject to inflation, still MVA is the measure that captures all dynamics of the firm performance (Ehrbar \& Hamel, 1997). MVA efficiently quantifies the share market's assessment of the net present value of a firm's past and expected capital investment projects (Lehn \& Makhija, 1996). Theoretically MVA at any point in time is the present value of respective yearly economic value added (EVA). Grant (1996) shows that if the firm's expected EVA is growing at some constant growth rate, $g$, each year forever, then the firm's market value-added can be expressed in a constant growth model.

$$
M V A=\frac{E V A_{1}}{r-g}
$$

Where MVA is current market value added, $\mathrm{EVA}_{1}$ is company current EVA outlook, $\mathrm{r}$ is cost of capital and $\mathrm{g}$ is growth rate in EVA.

As MVA is known for the firm performance in the long term and it is derived from market-generated number therefore, Kramer and Peters (2001) calculated MVA by subtracting the total capital employed in a company from the sum of the total market value of the company.

$$
\text { MVA = Total Market Value }- \text { Total Capital Employed }
$$

The total market value of firm is equal to the sum of market value of equity and market value of debt. MVA is the total excess value produced by the firm after paying dividends to its shareholder. In other words, MVA reflects the cumulative wealth created for shareholders over the existence of the company beyond the capital employed (Yook \& McCabe, 2001). From a practitioner's perspective, MVA captures the market's assessment of how effectively a company managers have used the scare resources under its control in addition to how well management has positioned the company (Cheng, Tsao, Tsai, \& Tu, 2007). If MVA is negative, then the market does not believe in the company's capacity to create value and the employed capital is eroded. On the contrary, a positive value proves that the company is very attractive on the market, because it can reward its shareholders (Yalcin et al., 2012).

Overall, MVA is an effective performance tool that evaluates the quality of strategic decisions and signals about the strategic change (Lehn \& Makhija, 1996). Therefore, it is reasonable to use MVA as a proxy for the measurement of owner wealth maximization.

\subsection{Cash Flow Return on Investment (CFROI)}

This performance measure is the close rival of economic value added in corporate performance evaluation comparison. It was first used in the 1970s by Callard, Madden \& Associates and later advanced by Holt Value Associates, which was acquired by Credit Suisse in 2002 (Thomas \& Gup, 2009). Cash Flow Return On Investment (CFROI) is defined as the sustainable cash flows that a company generates in a given year as percentage of the cash invested in the company asset (Erasmus \& Lambrechts, 2006). CFROI is similar to accounting ROI, but it is calculated by dividing discounted future cash flows by total capital assets. 


\section{Macrothink

CFROI is conceptually a simple model and is not restricted to accounting standards. The discounted cashflows represents future risk as it uses adjusted discount rate and are easily comparable with other firms, strategic business units and even product lines (Dzama, 2003; Erasmus \& Lambrechts, 2006). The CFROI model gets around accounting distortions and enables comparison among different firms and industries (Dzama, 2003; Young \& O'Byrne, 2001).

$$
\text { CFROI }=\frac{\text { Cash flows }- \text { Economic Depreciation }}{\text { Market Value of Capital Employed }}
$$

Where cash flow is gross operation cash flow, economic depreciation is the cost of depreciable assets consumed during a year, expressed in terms of opportunity cost of the original investment. According to Martin and Petty (2000) economic depreciation

$$
\text { Ecomomic Depreciation }=\left[\frac{W A C C}{(1+W A C C)^{t}}-1\right] X \text { Depreciating Assets }
$$

Where WACC is weighted average cost of capital and $t$ is asset life.

CFROI indicates whether the company has earned returns superior to its cost of capital and thus created value for its shareholders. In this sense, it shows an important similarity to EVA. Both measures assume that management creates value by earning returns on invested capital greater than the cost of capital. For the owners of the company or shareholders, high CFROI is an advantage because less money has to be invested to generate future growth.

\section{Methodology}

To decide whether AFP or MFP can explain variance in share prices, this study selected ASX 200 listed companies from 2001 to 2010. The majority of Australian companies use December as year-end for their reporting year. Some of the listed companies also report voluntary semi-annual financial statements to their stakeholders. We do not use these financial reports because of their tentative type of information. We used consolidated financial reports of parents companies as in forecasting context parent company accounting information is most relevant and have more influence on stock prices (Darrough \& Harris, 1991). We dropped companies with insufficient financial data and retained only those companies that have at least four consecutive years data. In our final sample we ended up with 164 companies from ten different sectors as shown in Table 1. 
Table 1. Sample composition

\begin{tabular}{lrr}
\hline \multicolumn{1}{c}{ INDUSTRY NAME } & \multicolumn{1}{c}{ Code } & Number of Companies \\
\hline Basic Materials & 1 & 43 \\
Consumer Goods & 2 & 07 \\
Consumer Services & 3 & 22 \\
Financials & 4 & 32 \\
Health Care & 5 & 08 \\
Industrials & 6 & 26 \\
Oil \& Gas & 7 & 14 \\
Technology & 8 & 02 \\
Telecommunications & 9 & 03 \\
Utilities & 10 & 07 \\
\hline Total & & 164 \\
\hline
\end{tabular}

The information required to calculate accounting and market based financial measures are downloaded from Datastream database. The dependent variable, stock return is calculated as change in year-end price divided by last year price. All prices are adjusted for dividend and taken from Datastream database. Correlation coefficients among dependant and independent variables are shown in Table 2.

We estimated five different models for each of the accounting as well as market based measures of financial performance: (1) a simple OLS model (Model_1), (2) cross-sectional fixed model (Model_2), (3) cross-sectional random model (Model_3), (4) cross-sectional and years fixed model (Model_4), and (5) cross-sectional and years random model (Model_5).

A simple model for accounting based information is as follows.

AdjRet $_{i t}=\alpha+\beta_{1}$ ROA $_{i t}+\beta_{2}$ ROE $_{i t}+\beta_{3} E P S_{i t}+\beta_{4} \operatorname{lnFCF_{it}}+\beta_{5} P O R_{i t}+\beta_{6}$ Size $_{i t}+\varepsilon_{i t}$

Where $A_{d j R e t}$ is the dividend adjusted stock return, $R O A$ is return on assets, $R O E$ is return on equity, EPS is earning per share, FCF is free cashflows, POR is dividend pay-out ratio, Size is the $\log$ of Total Assets, $i=1,2, \ldots, M$ cross sectional unit (companies) for periods $t=1,2, \ldots .$, T. $\varepsilon$ is error term with assumption of $\varepsilon_{i t} \sim \mathrm{N}\left(0, \sigma_{\varepsilon}^{2}\right)$.

A similar linear model is also estimated for market based related performance measures.

$$
\begin{aligned}
\text { AdjRet }_{i t}=\alpha & +\beta_{1} P 2 E_{i t}+\beta_{2} \operatorname{lnT} Q_{i t}+\beta_{3} \text { M2B }_{i t}+\beta_{4} \operatorname{lnMVA}_{i t}+\beta_{5} \text { CFROI }_{i t}+\beta_{6} \text { Size }_{i t} \\
& +\varepsilon_{i t}
\end{aligned}
$$

Where AdjRet $_{i t}$ is the dividend adjusted stock return, $P 2 E$ is price to earnings ratio, TBQ is tobin's Q, M2B is market to book ratio, MVA is market value added, CFROI is cash flow return on investment, Size is the $\log$ of Total Assets, $i=1,2, \ldots, M$ cross sectional unit (companies) for periods $t=1,2, \ldots . ., \mathrm{T}$. $\varepsilon$ is error term with assumption of $\varepsilon_{\mathrm{it}} \sim \mathrm{N}\left(0, \sigma_{\varepsilon}^{2}\right)$. 


\section{MIMacrothink}

Table 2. Correlation Matrix

\begin{tabular}{|c|c|c|c|c|c|c|c|c|c|c|c|}
\hline & $\begin{array}{l}\text { Ad. } \\
\text { Return }\end{array}$ & ROA & ROE & EPS & FCF & POR & P2E & TQ & M2B & MVA & CFROI \\
\hline Ad.Return & 1 & & & & & & & & & & \\
\hline ROA & 0.001 & 1 & & & & & & & & & \\
\hline ROE & -0.008 & $-0.043 *$ & 1 & & & & & & & & \\
\hline EPS & -0.006 & 0.048 & $0.118^{*}$ & 1 & & & & & & & \\
\hline FCF & $-0.046^{*}$ & 0.008 & 0.025 & $0.300^{* *}$ & 1 & & & & & & \\
\hline POR & $-0.157 * * *$ & 0.043 & $0.088^{* * *}$ & $0.205^{* * *}$ & $0.095 * * *$ & 1 & & & & & \\
\hline $\mathrm{P} 2 \mathrm{E}$ & -0.002 & 0.004 & 0.015 & 0.037 & 0.014 & $0.143 * * *$ & 1 & & & & \\
\hline TQ & -0.001 & $-0.75 * * *$ & $0.0585 * *$ & $-0.047 *$ & -0.014 & $-0687 * * *$ & $-0.105 * * *$ & 1 & & & \\
\hline M2B & 0.013 & 0.007 & -0.026 & 0.002 & -0.002 & -0.011 & $0.263 * * *$ & $0.437 * * *$ & 1 & & \\
\hline MVA & 0.035 & -0.001 & 0.012 & $0.143 * * *$ & $0.152^{* * * *}$ & $-0.0828 * * *$ & 0.0088 & 0.0138 & 0.011 & 1 & \\
\hline CFROI & -0.011 & 0.010 & $0.0786 * * *$ & $0.158^{* * *}$ & $0.445^{* * *}$ & $0.244 * * *$ & 0.0244 & -0.014 & -0.002 & $-0.0701 * * *$ & 1 \\
\hline
\end{tabular}

Notes: $(1) *$ denotes significance at $10 \%(\mathrm{p}<0.10),{ }^{* *}$ denotes significance at $5 \%(\mathrm{p}<0.05), * * *$ denotes

significance at $1 \%$

The assumption that observations are independent of from one another is very important in regression analysis. If it does not prevail, then the standard error of the estimate could be affected and the inferences that we make will be invalid.

If this is the case, then our model 2 or model 3 transformations may work better as it allows the impact of unobserved and time invariant factors that are specific to each firm. Model 1 in our study does not take into account differences across time and firms. It also assumes that coefficients are constant and has no effects and ignore the effects of such differences across firms and time using OLS. As this is very restrictive assumption hence, we allow the impact of time invariant factors that specific to firm (model $2 \&$ model 3 ) and across firms and time (model 4 and model 5).

Another important assumption in regression analysis is regarding the normality of residuals to ensure that the results of t-tests and F-test are valid and reliable. In this study we conducted Shapiro-Wilk W test for normality. The null hypothesis is that the distribution is normal. We reject the null hypothesis as the p-value is less than the cut-off point of 5\%. This result is aligned with existing literature (Deakin, 1976; Ezzamel \& Mar-Molinero, 1990; Ezzamel et al., 1987). However, to overcome this problem we ran bootstrap 2000 times to see whether the results of our models estimates are consistent. We found that the t-test value is stable and not changed significantly.

Since panel data analysis is used it is possible that observations contain intra-firm correlations. To avoid the effect of these correlations, the models used in this study provide results using robust standard errors cluster by company.

If two or more variables are in linear combination with one another it causes biased coefficient instability. The standard error of coefficients is also inflate. To check whether there is any relationship among independent variables we performed Variance Inflation 
Factor (VIF) tests. All variables had VIF values less than 10 which is considered to be satisfactory using the conventional rule of thumb (O’Brien, 2007).

\section{Results and Discussion}

Table 3 and Table 4 shows results of accounting based financial measures and market based financial measures respectively. Evidence shown in model 4 in both accounting and market based financial measures meets expectations.

Starting from Table 3, return on assets (ROA) is positively statistically significant at $1 \%$ level in the last four models and at 5\% in model 1, providing evidence that higher return on assets will result in higher stock rate of return. We also note that ROA is the only accounting based measure that is positively statistically significant in model 4 and 5 from a range of measures including its close counterpart measure ROE. It is pointing to the notion that stockholders are more concerned with the overall profitability of the firm compared to the return on their equity portion.

Table 3. Accounting based financial measures

\begin{tabular}{|c|c|c|c|c|c|}
\hline & Model_1 & Model_2 & Model_3 & Model_4 & Model_5 \\
\hline \multirow[t]{2}{*}{ ROA } & $0.7100 * *$ & $1.0519 * * *$ & $0.8444 * * *$ & $0.9272 * * *$ & $0.7771 * * *$ \\
\hline & $(2.47)$ & (3.34) & (2.99) & (3.95) & $(3.04)$ \\
\hline \multirow[t]{2}{*}{ ROE } & 0.1282 & 0.0278 & 0.0857 & 0.0452 & 0.0159 \\
\hline & $(0.81)$ & $(0.27)$ & $(0.65)$ & $(0.73)$ & $(0.15)$ \\
\hline \multirow[t]{2}{*}{ EPS } & $0.0504 * *$ & $0.0532 * *$ & $0.0501 * *$ & 0.0252 & 0.025 \\
\hline & $(2.06)$ & $(2.02)$ & (2.1) & (0.99) & (1.12) \\
\hline \multirow[t]{2}{*}{$\operatorname{lnFCF}$} & -0.0193 & -0.0155 & -0.012 & 0.0256 & 0.0075 \\
\hline & $(-0.86)$ & $(-0.43)$ & $(-0.46)$ & $(0.71)$ & $(0.32)$ \\
\hline \multirow[t]{2}{*}{ POR } & $-0.0031 * * *$ & -0.0007 & $-0.0027 * * *$ & $-0.0016^{* *}$ & $-0.0031 * * *$ \\
\hline & $(-3.79)$ & $(-0.8)$ & $(-3.37)$ & $(-2.07)$ & $(-4.11)$ \\
\hline \multirow[t]{2}{*}{ SIZE } & -0.0309 & 0.0241 & -0.0335 & 0.0366 & $-0.0465 * *$ \\
\hline & $(-1.52)$ & $(0.66)$ & $(-1.56)$ & (0.89) & $(-2.23)$ \\
\hline \multirow[t]{2}{*}{ Constant } & $0.9657 * * *$ & -0.0292 & $0.8995^{* * *}$ & -0.5915 & $0.8430 * * *$ \\
\hline & $(6.46)$ & $(-0.05)$ & $(4.8)$ & $(-0.91)$ & $(4.86)$ \\
\hline $\mathrm{N}$ & 1115 & 1115 & 1115 & 1115 & 1115 \\
\hline $\mathrm{R}^{2}$ & 0.1804 & 0.1519 & - & 0.2608 & - \\
\hline vce & Robust & Cluster & Robust & Cluster & Robust \\
\hline Firm effect & No & Yes & Yes & Yes & Yes \\
\hline Year effect & No & No & No & Yes & Yes \\
\hline
\end{tabular}

Notes: $(1) *$ denotes significance at $10 \%(\mathrm{p}<0.10)$, ** denotes significance at $5 \%(\mathrm{p}<0.05)$, *** denotes significance at $1 \%(\mathrm{p}<0.01)$; (2) Number in parenthesis below each coefficient show t-statistics

Similarly, pay-out ratio (POR) is negatively statistically significant at $1 \%$ in model 1 , model 3 , model 5 and $5 \%$ in model 4 . Pay-out ratio (POR) is insignificant only in model 2. It means that the stock rate of return decreases as the firm start paying its earning in the form of 
dividends. Stockholders are interested to reinvest earnings in the company rather to receive earning in the form of dividends.

Earning per share (EPS) is statistically significant in the first three models but after controlling for time variant effects, earning per share (EPS) turn statistically insignificant in model 4 and model 5. It shows that EPS is a time variant ratio. Stockholders may appreciate higher EPS in some years but in other years it may not be fully reflected in stock rate of return. Reported earnings that are used in formulation of EPS are quite sensitive to standards imposed by accounting bodies. We know that Australia adopted international accounting standards during our study period thus Australian investors may not have paid much attention to the change in this ratio over the years.

Overall, model 4 and model 5 (fixed effects and random effects controlling for both firm effects and years) are showing consistent and similar results in favour of return on asset (ROA) and pay-out ratio (POR). To decide which model give best results, we run the Hausman test to decide between fixed or random effects. The null hypothesis is that the preferred model is random effect over the fixed effect. For the accounting based performance measure models we fail to reject the null hypothesis at 5\% significance level. Therefore, the preferred model is random effects. Whereas, for the market based performance measures we rejected the null hypothesis meaning that the preferred model is fixed effects.

Analysing market based financial measures in Table 4; we note that only market to book ratio (M2B) is consistently significant throughout five models. Apart from model 1 which is significant at the $10 \%$ level, in the remaining four models M2B is strongly significant at the $1 \%$ level. These results are similar to Fama and French (1992) results that market to book ratio of individual stocks has the ability to explain cross sectional variation in stock returns. We find these results in the Australian market and thus market to book ratio (M2B) becomes one of the strong market based financial performance candidates to explain variance in stock prices.

Overall model 2 (fixed effect model controlling for firm effect) and model 4 (fixed effect model controlling for firm effect and years) meet expectations. The Hausman test is also in favour of fixed effect models. Four out of five market based measures; price to earning (P2E), Tobin's Q (TQ), market to book (M2B) and cashflow return on investment (CFROI) are statistically significant in both model 2 and model 4 . On other hand, the random effects model 3 and model 5 are showing only market to book (M2B) to be strongly statistically significant at the $1 \%$ level. 
Table 4. Market based financial measures

\begin{tabular}{|c|c|c|c|c|c|}
\hline & Model_1 & Model_2 & Model_3 & Model_4 & Model_5 \\
\hline \multirow[t]{2}{*}{$\mathrm{P} 2 \mathrm{E}$} & -0.0007 & $0.0020^{* *}$ & 0.0008 & $0.0019 * *$ & 0.0007 \\
\hline & $(-0.76)$ & (1.98) & $(0.88)$ & $(2.13)$ & $(0.9)$ \\
\hline \multirow[t]{2}{*}{$\operatorname{lnTQ}$} & 0.2293 & $0.9171^{*}$ & 0.5277 & $0.9573 * *$ & 0.5124 \\
\hline & (1.1) & $(1.96)$ & $(1.48)$ & $(2.07)$ & $(1.52)$ \\
\hline \multirow[t]{2}{*}{ M2B } & $0.0090^{*}$ & $0.0115^{* * *}$ & $0.0100^{* * *}$ & $0.0121^{* * *}$ & $0.0090 * * *$ \\
\hline & (1.91) & $(2.9)$ & $(3.03)$ & $(2.8)$ & $(2.61)$ \\
\hline \multirow[t]{2}{*}{$\operatorname{lnMVA}$} & 0.0733 & 0.0539 & 0.0837 & 0.0508 & 0.0388 \\
\hline & $(1.57)$ & $(0.63)$ & $(1.27)$ & $(0.65)$ & $(0.63)$ \\
\hline \multirow[t]{2}{*}{ CFROI } & 0.306 & $0.8978 * *$ & 0.6227 & $0.8725 * *$ & 0.6187 \\
\hline & $(0.74)$ & $(2.08)$ & $(1.43)$ & $(2.02)$ & $(1.53)$ \\
\hline \multirow[t]{2}{*}{ SIZE } & $-0.0947^{*}$ & 0.2493 & -0.02 & $0.3504 * *$ & -0.0177 \\
\hline & $(-1.96)$ & (1.56) & $(-0.26)$ & (2) & $(-0.25)$ \\
\hline \multirow[t]{2}{*}{ CONSTANT } & $0.6571 * *$ & $-4.1076 * * *$ & -0.5907 & $-5.3027 * * *$ & -0.3126 \\
\hline & $(2.45)$ & $(-2.63)$ & $(-1.07)$ & $(-2.91)$ & $(-0.63)$ \\
\hline $\mathrm{N}$ & 873 & 873 & 873 & 873 & 873 \\
\hline $\mathrm{R}^{2}$ & 0.1373 & 0.2283 & - & 0.1779 & - \\
\hline vce & Robust & Cluster & Robust & Cluster & Robust \\
\hline Firm effect & No & Yes & Yes & Yes & Yes \\
\hline Year effect & No & No & No & Yes & Yes \\
\hline
\end{tabular}

After analysing accounting and market based financial performance measures, we found that market based financial measures are performing better than accounting based financial measures in explaining stock returns. Two accounting ratios (return on asset (ROA) and pay-out ratio (POR)) and four market based ratios (price to earnings (P2E), Tobin Q (TQ), market to book (M2B) and cashflow return on investment (CFROI)) appear to be suitable candidates to explain stock return.

\section{Conclusions}

This study identifies suitable financial performance evaluation ratios from a range of available ratios for ASX 200 listed companies. A sequence of specification tests, panel regressions including both company and year fixed effects was selected as a reference model. After analysing and comparing 5 ratios from each of the sub-groups namely accounting based financial measure and market based financial measure, we find that price to earnings (P2E), Tobin Q (TQ), market to book (M2B) and cashflow return on investment (CFROI) from market based financial measures can better explain variance in stock prices. This makes a better group of performance evaluation measures over the rival approach where only return on asset (ROA) and pay-out ratio (POR) can explain stock return. This adds empirical evidence to the extant literature from an Australian market perspective. It reveals the inside story of the market participants that they pay more attention to market based measures over 
accounting based measures. These results are not only important from an academic research point of view but also to practitioners who rely on market based measures.

Given the strong relations of market financial performance measures and stock returns, future studies should focus on ratio and performance measures that are related to financial risk and their impact on market rate of return. More attention is required to investigate the motivation for behaviour that is inclined towards the market based measure. Market participants trust of accounting numbers and the effectiveness of financial reporting standards also requires attention from future researchers.

\section{References}

Anjum, S. (2010). An overview of financial ratios from 1900's till present days. International Journal of Research in Commerce \& Management, 1(8), 126-130.

Bell, E. T. (1945). The Development of Mathematics. New York: McGraw-Hill.

Bliss, J. H. (1923). Financial and Operating Ratios in Management. New York: The Ronald Press Company.

Chen, K. H., \& Shimerda, T. A. (1981). An empirical analysis of useful financial ratios. Financial Management, 10(1), 51-60. http://dx.doi.org/10.2307/3665113

Cheng, J. M. S., Tsao, S. M., Tsai, W. H., \& Tu, H. H. J. (2007). Will eChannel additions increase the financial performance of the firm? The evidence from Taiwan. Industrial Marketing Management, 36(1), 50-57. http://dx.doi.org/10.1016/j.indmarman.2006.06.011

Chung, K., \& Pruitt, S. (1994). A simple approximation of Tobin's q. Financial Management, 23(3), 70-74. http://dx.doi.org/10.2307/3665623

Cudia, C. P., \& Manaligod, G. T. (2011). EPS as a measure of intercompany performance: Philippine evidnece Journal of International Business Research, 10(1), 79-90.

Darrough, M. N., \& Harris, T. S. (1991). Do management forecasts of earnings affect stock prices in Japan? Journal of Accounting, Auditing, and Finance Supplement, 119-154.

Deakin, E. B. (1976). Distributions of financial accounting ratios: Some empirical evidence. The Accounting Review, 51(1), 90-96.

Dzama, A. (2003). Best practice technique: Focus on CFROI analysis to boost your firm's growth in 2004. IOMA's Report on Financial Analysis, Planning \& Reporting, 3(11), 10-12.

Ehrbar, A., \& Hamel, G. (1997). Debate: duking it out over EVA. Fortune, 136(3), 232.

Erasmus, P., \& Lambrechts, I. (2006). EVA and CFROI: A comparative analysis. Management Dynamics, 15(1), 14-26.

Ezzamel, M., \& Mar-Molinero, C. (1990). The distributional properties of financial ratios in UK manufacturing companies. Journal of Business Finance \& Accounting, 17(1), 1-29. http://dx.doi.org/10.1111/j.1468-5957.1990.tb00547.x 
Ezzamel, M., Mar-Molinero, C., \& Beech, A. (1987). On the distributional properties of financial ratios. Journal of Business Finance \& Accounting, 14(4), 463-481. http://dx.doi.org/10.1111/j.1468-5957.1987.tb00107.x

Fama, E. F., \& French, K. R. (1992). The cross-section of expected stock returns. The Journal of Finance, 47(2), 427-465. http://dx.doi.org/10.1111/j.1540-6261.1992.tb04398.x

Gallizo, J. L., \& Salvador, M. (2003). Understanding the behavior of financial ratios: The adjustment process. Journal of Economics and Business, 55(3), 267-283. http://dx.doi.org/10.1016/S0148-6195(03)00022-5

Gapenski, L. C. (1996). Using MVA and EVA to measure financial performance. Healthcare Financial Management, 50(3), 56-59.

Gilman, S. (1925). Analysing Financial Statements. New York: The Ronald Press Company.

Grant, J. L. (1996). Foundations of $\mathrm{EVA}^{\mathrm{TM}}$ for Investment Managers. The Journal of Portfolio Management, 23(1), 41-48. http://dx.doi.org/10.3905/jpm.1996.409573

He, X. (2012). Two sides of a coin: Endogenous and exogenous effects of corporate diversification on firm value. International Review of Finance, 12(4), 375-397. http://dx.doi.org/10.1111/j.1468-2443.2012.01158.x

Horrigan, J. O. (1968). A short history of financial ratio analysis. The Accounting Review, 43(2), 284-294.

Jordan, C. E., Clark, S. J., \& Smith, W. R. (2007). Should earnings per share (EPS) be taught as a means of comparing intercompany performance? The Journal of Education for Business, 82(6), 343-348. http://dx.doi.org/10.3200/JOEB.82.6.343-348

Jose, M. L., Lancaster, C., \& Stevens, J. L. (2011). Stability of excellence: Revealed patterns in Tobin's Q-ratios. Journal of Applied Business Research, 12(2), 83-91.

Jose, M. L., Nichols, L. M., \& Stevens, J. L. (1986). Contributions of diversification, promotion, and R\&D to the value of multiproduct firms: A Tobin's q approach. Financial Management, 15(4), 33-42. http://dx.doi.org/10.2307/3665778

Kramer, J. K., \& Peters, J. R. (2001). An interindustry analysis of economic value added as a proxy for market value added. Journal of Applied Finance, 11(1), 41-49.

Kumar, S., \& Warne, D. (2009). Parametric Determinants of Price-Earnings Ratio in Indian Capital Markets. The IUP Journal of Applied Finance, 15(9), 63-82.

Lehn, K., \& Makhija, A. K. (1996). EVA \& MVA as performance measures and signals for strategic change. Strategy \& Leadership, 24(3), 34-38. http://dx.doi.org/10.1108/eb054556

Lev, B., \& Sunder, S. (1979). Methodological issues in the use of financial ratios. Journal of Accounting \& Economics, 1(3), 187-210. http://dx.doi.org/10.1016/0165-4101(79)90007-7

Lindenberg, E. B., \& Ross, S. A. (1981). Tobin's Q ratio and industrial organization. Journal of Business, 54(1), 1-32. http://dx.doi.org/10.1086/296120 
Livingstone, J. L., \& Grossman, T. (2002). The Portable MBA in Finance and Accounting. Hoboken, New Jersey: John Wiley \& Sons Inc.

Martin, K. J. (1996). The method of payment in corporate acquisitions, investment opportunities, and management ownership. The Journal of Finance, 51(4), 1227-1246. http://dx.doi.org/10.1111/j.1540-6261.1996.tb04068.x

Martin, P. D., \& Petty, J. W. (2000). Value based management: The corporate response to the shareholder revolution. Boston: Havard Business School Press.

McConnell, J. J., \& Servaes, H. (1990). Additional evidence on equity ownership and corporate value. Journal of Financial Economics, 27(2), 595-612. http://dx.doi.org/10.1016/0304-405X(90)90069-C

Moyer, R. C., McGuigan, J. R., \& Kretlow, W. J. (1992). Contemporary Financial Management. Mason: South-Western Cengage Learning.

Nikolai, L., \& Bazley, J. (2010). Intermediate Accounting. Mason: South-Western Cengage Learning.

O'Brien, R. M. (2007). A caution regarding rules of thumb for variance inflation factors. Quality \& Quantity, 41(5), 673-690. http://dx.doi.org/10.1007/s11135-006-9018-6

Olibe, K. O., Ehie, I. C., \& Strawser, W. R. (2012). Corporate diversification, firm value and operating performance: Testing the relevance of segment accounting data. International Journal of Accounting, Auditing and Performance Evaluation, 8(2), 184-202. http://dx.doi.org/10.1504/IJAAPE.2012.046707

Palepu, K. G., Healy, P. M., Bernard, V. L., Wright, S., Bradbury, M., \& Lee, P. (2010). Business Analysis \& Valuation: Using Financial Statements (4ed.). Mason: South-Western Cengage Learning.

Pandya, A. M., \& Rao, N. V. (1998). Diversification and firm performance: An empirical evaluation. Journal of Financial and Strategic Decisions, 11(2), 67-81.

Perfect, S. B., \& Wiles, K. W. (1994). Alternative constructions of Tobin's q: An empirical comparison. Journal of Empirical Finance, 1(3), 313-341. http://dx.doi.org/10.1016/0927-5398(94)90007-8

Salmi, T., \& Martikainen, T. (1994). A review of the theoretical and empirical basis of financial ratio analysis. The Finnish Journal of Business Economics, 43(4), 426-448.

Sandoval, E. (2001). Financial performance measures and shareholder value creation: An empirical study for Chilean companies. Journal of Applied Business Research, 17(3), 109-123.

Singh, A., \& Schmidgall, R. S. (2002). Analysis of financial ratios commonly used by US lodging financial executives. Journal of Retail \& Leisure Property, 2(3), 201-213. http://dx.doi.org/10.1057/palgrave.rlp.5090210 
Smith, D. E. (1925). History of Mathematics (Vol. II). Bostan: Ginn \& Company.

Sorter, G. H., Becker, S. W., Archibald, T. R., \& Beaver, W. (1964). Corporate personality as reflected in accounting decisions: Some preliminary findings. Journal of Accounting Research, 2(2), 183-196. http://dx.doi.org/10.2307/2490000

Thomas, R., \& Gup, B. E. (2009). The valuation handbook: valuation techniques from today's top practitioners (Vol. 480): John Wiley \& Sons Inc. http://dx.doi.org/10.1002/9781118268179

Tong, T. W., Alessandri, T. M., Reuer, J. J., \& Chintakananda, A. (2008). How much does country matter? An analysis of firms' growth options. Journal of International Business Studies, 39(3), 387-405. http://dx.doi.org/10.1057/palgrave.jibs.8400355

Truong, C. (2009). Value investing using price earnings ratio in New Zealand. University of Auckland Business Review, 12(1), 1-7.

Wall, A. (1919). The study of Barometrics. Federal Reserve Bulletine

Williams, J. R. (2000). GAAP guide, college edition. San Diego, CA: Harcourt Professional.

Yalcin, N., Bayrakdaroglu, A., \& Kahraman, C. (2012). Application of fuzzy multi-criteria decision making methods for financial performance evaluation of Turkish manufacturing industries. Expert Systems with Applications, 39(1), 350-364. http://dx.doi.org/10.1016/j.eswa.2011.07.024

Yook, K. C., \& McCabe, G. M. (2001). MVA and the cross-section of expected stock returns. The Journal of Portfolio Management, 27(3), 75-87. http://dx.doi.org/10.3905/jpm.2001.319803

Young, S. D., \& O'Byrne, S. F. (2001). EVA and value-based management: A practical guide to implementation. Martinsburg: McGraw-Hill. 